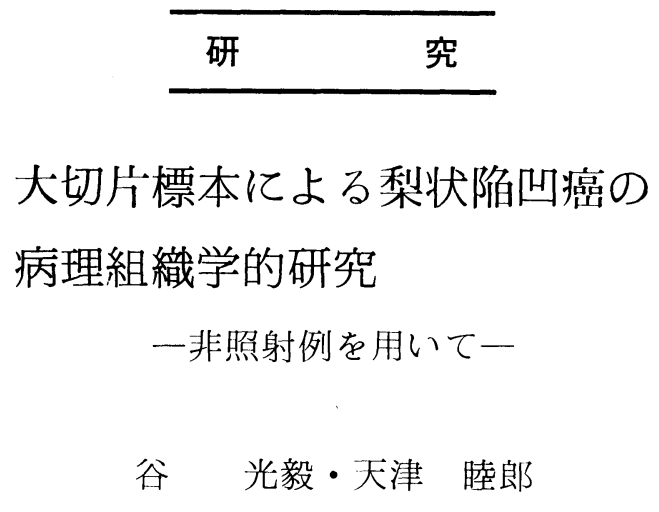

\title{
Histopathological Study of Cancer of the Piriform Sinus by Whole-Organ Serial Sectioning
}

\author{
Mitsutake Tani and Mutsuo Amatsu \\ (Kobe University)
}

Hypopharyngeal cancer is one of the most dreaded and distressing diseases in the head and neck region with respect to the aggressive treatment modalities employed and its poor prognosis. It is significant for obtaining a better prognosis to estimate histopathologically the modes of growth and spread of this tumor. Twenty surgical specimens removed for piriform sinus cancer were studied histopathologically by whole-organ serial sectioning.

1) The modes of extension of tumor to the laryngeal cartilages were classified into two groups, contact and invasion. Invasion of the cartilage occurred in the ossified parts.

2) The tumor frequently extended laterally outside the thyroid ala with invasion of the thyroid cartilage $(25 \%)$ or around the thyroid cartilage without invasion $(40 \%)$. Therefore, the thyroid cartilage did not seem to be a barrier against lateral extension of cancer.

3) When tumor extended medially to invade laryngeal structures, vocal cord fixation occurred in $70 \%$. Vocal cord fixation was due mainly to involvement of the intrinsic laryngeal muscles and not to involvement of the arytenoid cartilage or the cricoarytenoid joint.

4) Upward growth was usually extensive because of the lack of any barrier. Invasion of the false vocal cord occurred by the direct retrograde submucosal route beyond the aryepiglottic fold.

5) Downward extension was relatively slight compared to upward extension.

6) A satisfactory margin of normal pharyngeal mucosa must be removed with the specimen at the time of operation. In piriform sinus cancer at least $2 \mathrm{~cm}$ is thought to be necessary, in view of the submucosal extension. 
下咽頭癌は，頭頸部領域では予後不良の癌として知られている ${ }^{2324) 25)}$ ，その理由は幾つか挙げら れるが, 局所的には病理組識学的進展度を術前, 術中に的確に把握し難いととを指摘できる。癌の 進展度をいろい万な角度から正確に知ることは, 治療成績向上の必須の条件となるが, 下咽頭癌で はこの点に関する研究が意外に少ない，大切片䌘本による研究では，欧米においては，Ogura ${ }^{100}$, Kirchner $^{9)}$, Olofsson ${ }^{8)}$, Harrison ${ }^{11)} ら の$ 報告がみられるが，本邦においては，頸部食道癌を主 とした木村 ${ }^{18)}$ の報告以外はほとんどみあたらない。

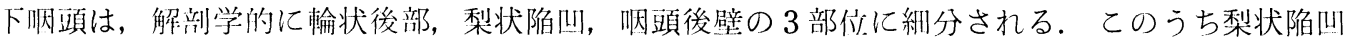
に住:じる癌は最も多く，およそ 3 分の 2 を占める。手術にあたっては，梨状陷四を含む拡大喉頭全

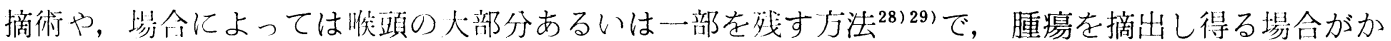
なり多くみられる。乙の晹合，腫瘍摘出後の残存咽頭粘膜を用いて，一次的に食物の通路の形成が 可能となる. 従って, 輪状後部癌, 呐頭後壁癌に比べると, 頻度の上からも, 臨床上の取扱いの上 からむ, やや趣を異にする。乙うした点から, 著者は梨状陷凹癌に着目し, 摘出標本をもとに腫煌 の進展方向，進展範囲，進展様式を詳細に検討することにより，梨状陷凹癌の生物学的特性を解明 する目的で本研究を行なった。

\section{研究対象および方法}

詔和47年より昭和58年までの12年間に，神戸 大学耳鼻咽喉科を受診した下゙咽頭癌 117 症例の 中で，梨状侔四に原発するものは77例（66\%） であった（表 1 ）。乙れを一次治療別に分類す ると，術前に放射線治療を行なわなかった症。 例，すなわち手術単独例と手術十術後照射例は 計23例であった（表 2 ）。この中から，摘出䌘 本の保存状態の良好なもの20例を選び，検索対 象とした。年令は 48〜81才で，性別は男性19 例，反性 1 例， $\mathrm{T}$ 分類によるうち分けは， $\mathrm{T}_{1}$ 2 例, $\mathrm{T}_{2} 2$ 例, $\mathrm{T}_{3} 12$ 例, $\mathrm{T}_{4} 4$ 例であった。 な お T NM分類は，頭頸部癌取扱い規約（1982） に従った。手術は 17 例に咽喉摘，3例に咽喉食 摘を施行し， 1 例を除いて全例に，同時に頸部

表 2 梨状陷凹癖

表 I 下咽頭癌

(1972 1983)

\begin{tabular}{cc}
\hline 梨状陷凹 & 77 \\
輪状後部 & 30 \\
咽頭後旺 & 10 \\
\hline
\end{tabular}

計

117
郭清術を併用した（表 3 ）。

研究方法は，まず摘出䌘本を詳細に観察し， 肉眼的所見をスケッチで垶録し，あわせて写真 撮影を行なった。 その後, $10 \%$ ホルマリンで固 定された眎本を一塊のまま水洗，アルコールに よる脱水および脱脂，キレート骺と塩酸による 脱灭を行なった後, 正中で矢状断し，患側半分 を水平断で， $4 \mathrm{~mm}$ 間隔で連続的に切り出した

（図 1)。その後同様の操作で, 再度水洗, 脱 水，脱脂，脱灰を行ない，パラフィン包埋にて $8 \sim 15 \mu$ に薄切し, $\mathrm{H}-\mathrm{E}$ 染色を施し， 1 例あ たり $8 \sim 15$ 枚の段階的大切片標本を作製した.

(1972 1983)

手術単独 20

手術 + 術後照射 3 放射線治療単独 43 根治照射後再発山手術 8 術前照射十手術 3 計 77 


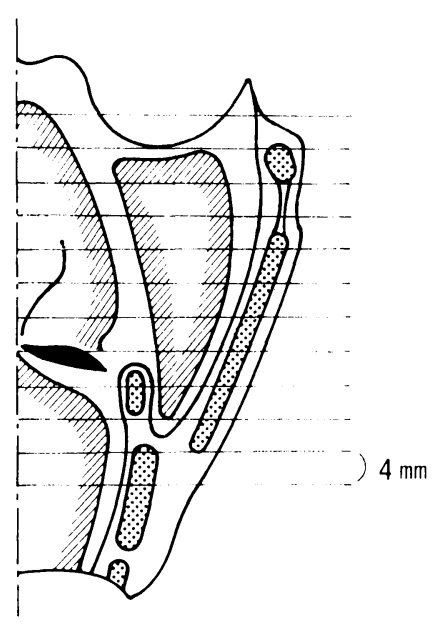

図 1 標本の切り出し

反対側への腫瘍の進展が疑われた例には, 反対 側の大切片標本も同様にして作製した。これら の標本をもとに，以下の項目につき検討した (表 4 ).

1.腫瘍の組織型

2 . 腫瘍の組織学的悪性度

腫瘍の組織型の中で扁平上皮癌につき Will$\mathrm{én}^{26)}$ の分類に基づき, 腫瘍の組織学的悪性度 を検討した. Willén の分類之は，腫煬細胞の (1)分化度, (2)核異型性, (3)分裂, 宿主反応とし

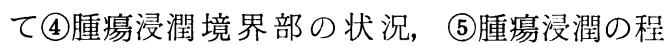
度, 6間質細胞浸潤の計 6 項目につき, 各 4 段 階で $1 \sim 4$ 点の点数をつけ, その合計により組 織学的悪性度を判定するものである（表 5 ).

3. 腫瘍の諸構造物心の深達

1) 喉頭軟骨

表 3 検索対象になった梨状陥凹癌20例の臨床経過

\begin{tabular}{|c|c|c|c|c|c|}
\hline $\begin{array}{l}\text { 症例 } \\
\text { 番号 }\end{array}$ & 年柃/性 & T NM分類 & 治 & \multicolumn{2}{|r|}{ 術後転帰（死因） } \\
\hline 1 & 70 男 & $\mathrm{T}_{3} \mathrm{~N}_{0} \mathrm{M}_{0}$ & P L + R-R N D & 9 年 5 月 & 死（老衰） \\
\hline 2 & 64 男 & $\mathrm{T}_{2} \mathrm{~N}_{3} \mathrm{M}_{0}$ & P L + R-R N D & 1 年10月 & 死（頸部再発，肺転移） \\
\hline 3 & 64 男 & $\mathrm{T}_{4} \mathrm{~N}_{0} \mathrm{M}_{0}$ & $\mathrm{P} L \Rightarrow \mathrm{R}-\mathrm{RND}+\mathbb{R}$ & 1 年 5 月 & 死（頸部再発） \\
\hline 4 & 78 男 & $\mathrm{T}_{3} \mathrm{~N}_{3} \mathrm{M}_{0}$ & P L $+\mathrm{L}-\mathrm{R}$ ND & 1 年 2 月 & 死（頸部再発） \\
\hline 5 & 73 男 & $\mathrm{T}_{3} \mathrm{~N}_{3} \mathrm{M}_{0}$ & P L E + R-R N D & 9 月 & 死（頸部再発，肺転移） \\
\hline 6 & 71 男 & $\mathrm{T}_{4} \mathrm{~N}_{0} \mathrm{M}_{0}$ & $\mathrm{P} L+\mathrm{L}-\mathrm{RND}+\mathbb{R}$ & 6 年 & 生 \\
\hline 7 & 74 男 & $\mathrm{T}_{3} \mathrm{~N}_{1} \mathrm{M}_{0}$ & $\mathrm{PL}+\mathrm{L}-\mathrm{R} \mathrm{ND} \Leftrightarrow \mathrm{R}-\mathrm{R} \mathrm{ND}$ & 5 年 & 生 \\
\hline 8 & 64 男 & $\mathrm{T}_{1} \mathrm{~N}_{1} \mathrm{M}_{0}$ & P L E + B - R N D & 10月 & 死(局所再発, 頸部再発) \\
\hline 9 & 69 男 & $\mathrm{T}_{3} \mathrm{~N}_{1} \mathrm{M}_{0}$ & P L + L-R ND & 2 年 & 死（頸部再発，肺転移） \\
\hline 10 & 52 男 & $\mathrm{T}_{4} \mathrm{~N}_{1} \mathrm{M}_{0}$ & $\mathrm{P} \mathrm{L}+\mathrm{B}-\mathrm{R} \mathrm{ND}+\mathbb{R}$ & 7 月 & 死（肺転移） \\
\hline 11 & 54 男 & $\mathrm{T}_{3} \mathrm{~N}_{1} \mathrm{M}_{n}$ & $\mathrm{P} L+\mathrm{L}-\mathrm{R} \mathrm{ND} \Rightarrow \mathrm{R}-\mathrm{R} \mathrm{ND}+\mathrm{R}$ & 2 年 & 死（肺転移） \\
\hline 12 & 48 男 & $\mathrm{T}_{3} \mathrm{~N}_{3} \mathrm{M}_{0}$ & P L + R-R ND & 2 年10月 & 生 \\
\hline 13 & 52 女 & $\mathrm{T}_{2} \mathrm{~N}_{1} \mathrm{M}_{0}$ & $\mathrm{P} L+\mathrm{R}-\mathrm{R} \mathrm{N} \mathrm{D}+\mathbb{R}$ & 1 年 & 死(局所再発，頸部再発) \\
\hline 14 & 56 男 & $\mathrm{T}_{3} \mathrm{~N}_{1} \mathrm{M}_{0}$ & $\mathrm{P} L+\mathrm{R}-\mathrm{R} \mathrm{ND} \Rightarrow \mathrm{L}-\mathrm{R} \mathrm{ND}$ & 1 年 8 月 & 死（局所再発） \\
\hline 15 & 74 男 & $\mathrm{T}_{3} \mathrm{~N}_{1} \mathrm{M}_{0}$ & $\mathrm{P} \mathrm{L}+\mathrm{B}-\mathrm{R} \mathrm{ND}$ & 1 年 2 月 & 死（心疾患） \\
\hline 16 & 69 男 & $\mathrm{T}_{3} \mathrm{~N}_{1} \mathrm{M}_{0}$ & $P L E+L-R N D \Rightarrow R-R N D$ & 1 年10月 & 生 \\
\hline 17 & 59 男 & $\mathrm{T}_{3} \mathrm{~N}_{1} \mathrm{M}_{0}$ & $\mathrm{P} L+\mathrm{R}-\mathrm{R} \mathrm{ND}$ & 1 年 5 月 & 生 \\
\hline 18 & 67 男 & $\mathrm{T}_{4} \mathrm{~N}_{1} \mathrm{M}_{0}$ & P L $+\mathrm{L}-\mathrm{R} \mathrm{ND}$ & 1 年 & 生 \\
\hline 19 & 73 男 & $\mathrm{T}_{1} \mathrm{~N}_{1} \mathrm{M}_{0}$ & $\mathrm{P} L+\mathrm{R}-\mathrm{R} \mathrm{ND} \Rightarrow \mathrm{L}-\mathrm{R} \mathrm{ND}$ & 6 月 & 生 \\
\hline 20 & 81 男 & $\mathrm{T}_{3} \mathrm{~N}_{1} \mathrm{M}_{0}$ & $\mathrm{P} \mathrm{L}+\mathrm{R}-\mathrm{R} \mathrm{ND}$ & 2 年 8 月 & 生 \\
\hline
\end{tabular}

PL : Partial pharyngectomy-total laryngectomy, R : Right, L : Left,

B : Bilateral, RND : Radical Neck Dissection, $(\mathbb{R})$ : Postoperative radiation 
腫瘍の軟骨いの進展様式を，2つの型に分類てて腫瘍が軟骨内へ汥潤するものを浸潤例とし した。すなわち，腫瘍が軟骨膜まで達するが， 軟骨膜が barrier となって軟骨内八の浸潤が みられないものを接触例之し，軟骨膜を破壊し た.ての分類を基準にして，以下の喉頭軟骨に ついて検㬏た。

(1)甲状軟骨

表 4 検 討 項 目

1. 腫焬の組織型

2. 腄煌の組織学的悪性度

3. 腫焬の諸構造物への深達

1) 喉頭軟骨

(1)甲状軟骨

(2)輪状軟骨

(3)披裂軟骨

(4)喉頭蓋軟骨

2 ）輪状披裂関節

3) 内喉頭筋

(1)甲状披裂筋

(2)後輪状披裂笳

(3)外側輪状披裂筋

(4)披裂筋

4) 披裂喉頭莣七ダ
5 ) 㮢頭蓋前領域

6 ) 仮声帯

7 ) 声帯

8 ) 咽頭喉頭蓋ヒダ

9) 甲状舌骨膜

10）梨状陥凹先端部

11）気管

12）甲状腺

13）輪状後部

14）顇部食道

4. 反対側諸構造物

5. 表面進展型梨状陥山癌

6. 原発部位. と進展度

7. 粘膜下進展度

8. 脈管侵襲

表 5 Histological grading of malignancy (Willén)

\begin{tabular}{|c|c|c|c|c|}
\hline & \multicolumn{4}{|c|}{ I Tumor cell population } \\
\hline & 1 & 2 & 3 & 4 \\
\hline (1) Differentiation & $\begin{array}{l}\text { Highly, keratini- } \\
\text { zation }\end{array}$ & $\begin{array}{r}\text { Moderately, some } \\
\text { keratinization }\end{array}$ & Poorly minimal & $\begin{array}{l}\text { Poorly no } \\
\text { keratinization }\end{array}$ \\
\hline $\begin{array}{l}\text { (2) Nuclear poly- } \\
\text { morphism }\end{array}$ & Few enlarg. nuclei & $\begin{array}{r}\text { Moderate number } \\
\text { of enlarged } \\
\text { nuclei }\end{array}$ & $\begin{array}{r}\text { Numerous irregular } \\
\text { enlarged nuclei }\end{array}$ & $\begin{array}{c}\text { Anaplastic } \\
\text { immature } \\
\text { enlarged nuclei }\end{array}$ \\
\hline \multirow[t]{3}{*}{ (3) Mitosis } & Single & Moderate number & Great number & Numerous \\
\hline & \multicolumn{4}{|c|}{ II Tumor-host relationship } \\
\hline & 1 & 2 & 3 & 4 \\
\hline $\begin{array}{l}\text { (4) Mode of } \\
\text { invasion }\end{array}$ & $\begin{array}{l}\text { Well defined } \\
\text { borderline }\end{array}$ & Cords, less marked & $\begin{array}{l}\text { Groups of cells, no } \\
\text { distinct borderline }\end{array}$ & Diffuse invasion \\
\hline $\begin{array}{l}\text { (5) Stage of } \\
\text { invasion }\end{array}$ & Susp. & $\begin{array}{l}\text { Microcarcinoma } \\
\text { few cords }\end{array}$ & $\begin{array}{l}\text { Nodular invasion } \\
\text { connective tissue }\end{array}$ & Massive invasion \\
\hline $\begin{array}{l}\text { (6) Cellular } \\
\text { respones }\end{array}$ & Marked & Moderate & Slight & None \\
\hline
\end{tabular}


(2)輪状軟骨

(3)披裂軟骨

(4)喉頭蓋軟骨

2 ）輪状披裂関節

腫瘍先端部が，輪状披裂関節の関節囊に接す る状態であるが，関節囊に変化が認められない ものを接触例，関節囊内一腫湯が浸潤するもの を浸潤例とした。

3 ) 内喉頭筋

内喉頭筋八の深達については，腫瘍先端部が 筋膜まで達するが，筋膜が barrier となって 筋層へ没潤がみられないものを接触例，筋膜を 破壊して筋層へ浸潤するものを浸潤例とし，以 下し)笳肉について検討した。
(1)甲状披裂笳
(2)後輪状披裂筋
(3)外側輪状披裂筋

(4)披裂筋

4 ）披裂喉頭蓋ヒダ

5 ）喉頭蓋前領域

6 ) 仮声带:

7 ) 声带

8 ）咽頭喉頭蓋ヒダ

9 ) 甲状舌骨膜

10）梨状陥凹先端部

11）気管

12）甲状腺

13）輪状後部

14）頸部食道

4. 反対側諸構造物

5. 表面進展型梨状陷汇癌

6. 原発部位と進展度

7. 粘膜下進展度

8. 脈管侵襲

\section{研 究 結 果}

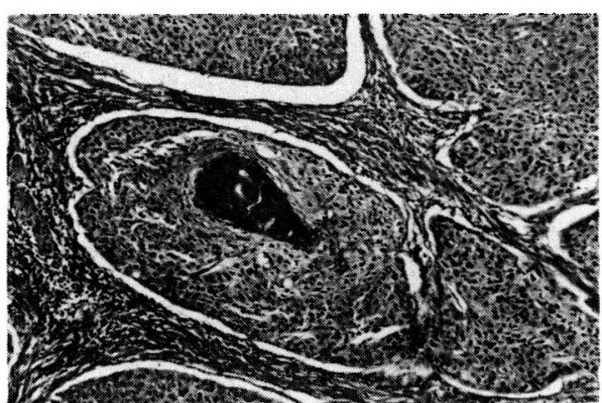

図 2 高分化型扁平上皮癌（症例11，×33）

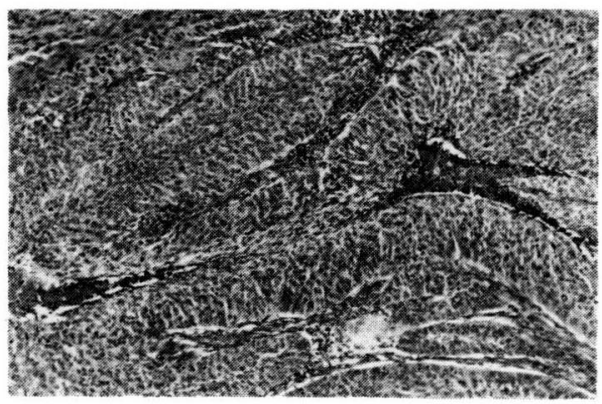

図 3 中分化型扁平上皮癌（症例 $9, \times 33$ )
1. 腫瘍の組織型

腫瘍の組織型は, 扁平上皮癌18例, 癌肉腫 2 例であった．図 2 が症例11で高分化型扁平上皮 癌, 図 3 が症例 9 で中分化型扁平上皮癌，図 4 が症例 6 で癌肉腫である。

2 . 腫場の組織学的悪性度

Willén の分類に基づき, 扁平上皮癌18例に つき各項目ごとに検討した結果が表 6 である。 分化度は高分化型10例, 中分化型 8 例, 低分化

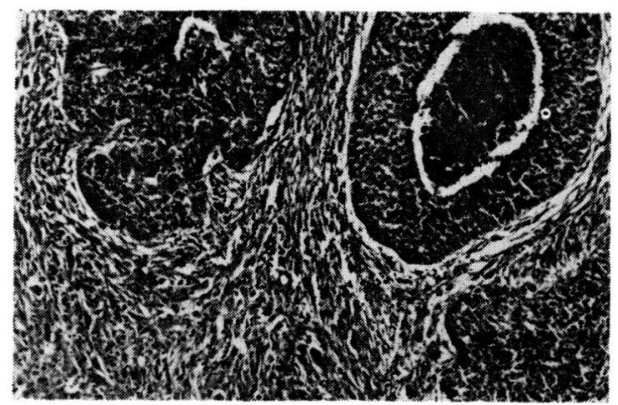

图 4 癌肉腫（症例 $3, \times 33 ）$ 
型は 2 例の癌肉腫の扁平上皮癌の部分において 認められた。同一切片において屯，部位により 異った分化度を示すととが多かった。全体的に みると，核異型性は軽度で，分裂像は中等度に みられた。また宿主反応として腫瘍浸潤境界部 はよく織別できるが, 腫瘍浸潤の程度が強かっ た。間質細胞浸潤は，症例によりばらつきがあ った．悪性度点数は $8 \sim 12$ 点であった。

3. 腫演の諸構造物への深達

1) 喉頭軟骨

(1)甲状軟骨

甲状軟骨には18例（90\%）に深達が認めら れ，接触例12例，浸潤例 6 例であった。術前早 期癌と考えられた $\mathrm{T}_{1}, \mathrm{~T}_{2}$ の 4 例全例に既に深
達を認め, うち半数の 2 例に軟骨内浸潤を認め た（表 7 )。軟骨膜は腫瘍の接近に伴い，正常 に較べ線維性に肥厚することが多く，また圧迫 の強い部位では菲薄化していた（図 5 ).

軟骨内浸潤例 6 例について検徖すると，軟管 が破壊される部位は，全例とも軟骨の化骨部位。 で，軟骨の後縁および下縁であった(図6，7）。 軟骨内一浸潤した後の進展は，1例では軟骨内 に留まっていたが，他い 5 例では外側ひ軟骨膜 屯破壊され，甲状軟骨外方の軟部組織へ進展し ていた。

一方, 外方いの進展が, 軟骨膜の防御機構に より妨げられた症例では，甲状軟骨の後縁を軟 骨膜沿いに迂回し，外方八進展する傾向にあっ

表 6 各症例の組織学的悪性度

\begin{tabular}{|c|c|c|c|c|c|c|c|c|}
\hline \multirow{3}{*}{$\begin{array}{l}\text { Case } \\
\text { No. }\end{array}$} & \multirow{3}{*}{$\begin{array}{l}\text { Histo- } \\
\log y\end{array}$} & \multicolumn{7}{|c|}{ Histological grading of malignancy (Willén) } \\
\hline & & \multicolumn{3}{|c|}{ Tumor cell population } & \multicolumn{3}{|c|}{ Tumor-host relationship } & \multirow{2}{*}{$\begin{array}{r}\text { Malignancy } \\
\text { points }\end{array}$} \\
\hline & & $\begin{array}{r}\text { Differentia- } \\
\text { tion }\end{array}$ & $\mid \begin{array}{r}\text { Nuclear poly- } \\
\text { morphism }\end{array}$ & Mitosis & $\begin{array}{c}\text { Mode of } \\
\text { invasion }\end{array}$ & $\left|\begin{array}{|}\text { Stage of } \\
\text { invasion }\end{array}\right|$ & $\mid \begin{array}{c}\text { Cellular } \\
\text { response }\end{array}$ & \\
\hline 1 & $\mathrm{SCC}$ & 2 & 1 & 2 & 2 & 4 & 1 & 12 \\
\hline 2 & $\mathrm{~S} \mathrm{C} \mathrm{C}$ & 1 & 1 & 2 & 1 & 3 & 2 & 10 \\
\hline 3 & $\mathrm{C} \mathrm{S}$ & & & & & & & \\
\hline 4 & $\mathrm{SCC}$ & 1 & 1 & 1 & 1 & 3 & 1 & 8 \\
\hline 5 & $\mathrm{SCC}$ & 2 & 2 & 1 & 1 & 3 & 1 & 10 \\
\hline 6 & $\mathrm{C} \mathrm{S}$ & & & & & & & \\
\hline 7 & $\mathrm{SCC}$ & 2 & 1 & 2 & 1 & 3 & 1 & 10 \\
\hline 8 & $\mathrm{SCC}$ & 1 & 1 & 2 & 1 & 3 & 2 & 10 \\
\hline 9 & $\mathrm{SCC}$ & 2 & 1 & 3 & 1 & 3 & 2 & 12 \\
\hline 10 & $\mathrm{SCC}$ & 1 & 1 & 2 & 1 & 3 & 1 & 9 \\
\hline 11 & $\mathrm{SCC}$ & 1 & 1 & 1 & 1 & 4 & 1 & 9 \\
\hline 12 & $\mathrm{SCC}$ & 2 & 1 & 1 & 1 & 3 & 3 & 11 \\
\hline 13 & $\mathrm{SCC}$ & 2 & 1 & 2 & 1 & 3 & 3 & 12 \\
\hline 14 & $\mathrm{SCC}$ & 2 & 1 & 2 & 1 & 3 & 3 & 12 \\
\hline 15 & $\mathrm{SCC}$ & 1 & 1 & 1 & 1 & 3 & 1 & 8 \\
\hline 16 & $\mathrm{SCC}$ & 2 & 3 & 2 & 1 & 3 & 1 & 12 \\
\hline 17 & $\mathrm{SCC}$ & 1 & 1 & 2 & 1 & 3 & 2 & 10 \\
\hline 18 & $\mathrm{SCC}$ & 1 & 2 & 1 & 1 & 3 & 1 & 9 \\
\hline 19 & $\mathrm{SCC}$ & 1 & 1 & 2 & 1 & 3 & 1 & 9 \\
\hline 20 & $\mathrm{SCC}$ & 1 & 1 & 2 & 1 & 3 & 2 & 10 \\
\hline
\end{tabular}

SCC : Squamous Cell Carcinoma, CS : Carcinosarcoma 
た. $\mathrm{T}_{3}, \mathrm{~T}_{4}$ の接触例10例中 8 例に，このよう な迂回外万進展が観察された（図 8 ）。 また接 触例12例中 7 例では，外少進展を制限された腫 場が, 甲状軟骨内縁に沿うように上方へ進展し ていた.

(2)輪状軟骨

輪状軟骨には 9 例 $(45 \%)$ 飞深達が認めら

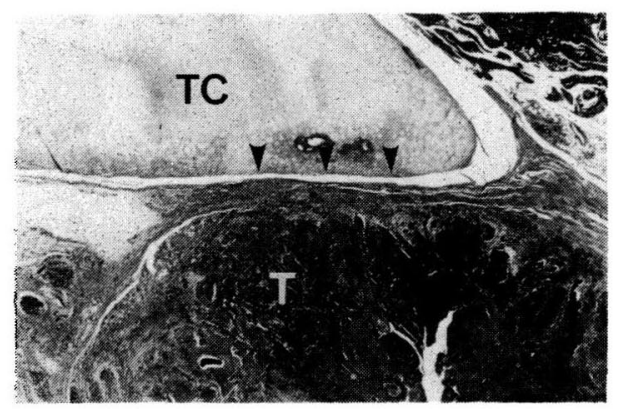

図 5 軟骨膜の線維性肥厚（症例 $9, \times 3.3$ ) 矢印に腫場の接近による甲状軟骨膜の肥厚を示す。 $\mathrm{T} ：$ 腫焬 T C : 甲状軟骨
れ, 接触例 8 例, 浸潤例 1 例であった（表 7 ）. 接触例 8 例を $\mathrm{T}$ 分類別にみると, $\mathrm{T}_{2} 1$ 例, $\mathrm{T}_{3}$ 5 例， $\mathrm{T}_{4} 2$ 例であった（図 9 ). 浸潤例の 1 例 （症例10）は $\mathrm{T}$ なであった。腫瘍が輪状軟骨之
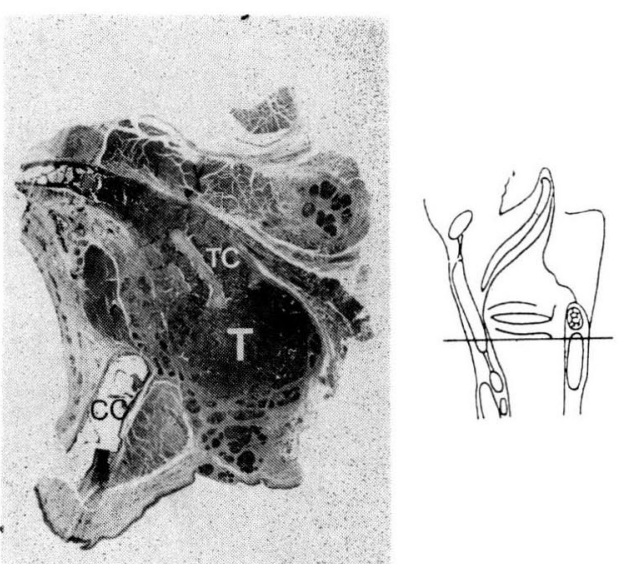

图 7 甲状軟骨への浸潤（症例 $6, \times 1$ ) $\mathrm{T}$ ：腫場 T C : 甲状軟情 C C : 輪状軟骨

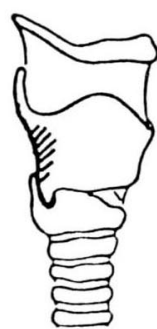

(症例 2 )

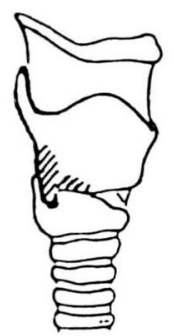

(症例16)

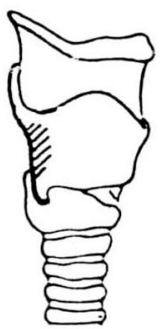

(症例 4)

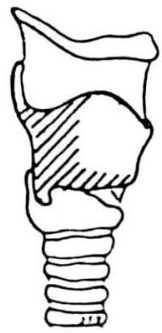

(症例18

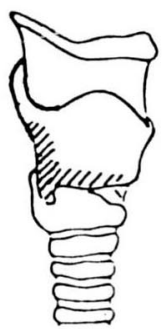

(症例 6 )

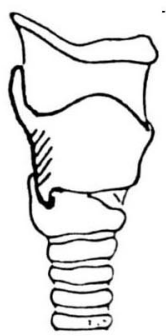

(症例19

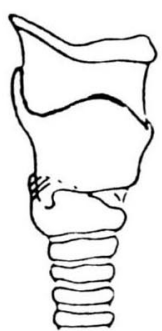

(症例10)

図 6 甲状軟骨および輪状軟骨への浸潤 斜線部に浸潤部位を示す. 
接触する部位は， 8 例中 7 例で輪状披裂関節の 近傍であり，浸潤も同部位で生じていた（図 6 ).

(3)披裂軟骨

披裂軟骨には10例（50\%）に深達を認めた が，全例が接触例で，腫煬が軟骨を取り囲む邚 く進展して屯, 軟骨内へ浸潤する例はみられな かった. $\mathrm{T}$ 分類別にみると, $\mathrm{T}_{3} 8$ 例, $\mathrm{T}_{4} 2$ 例 であった（表 7 ).

披裂軟骨へ達した腫瘍は，軟骨を避け，前内 方では甲状披裂筋，後内力では後輪状披裂筋や 披裂筋八深達する。甲状披裂筋一は接触例 1 例, 浸潤例 7 例の計 8 例に深達を認め, 後輪状 披裂筋へは接触例 3 例, 浸潤例 3 例凹計 6 例,

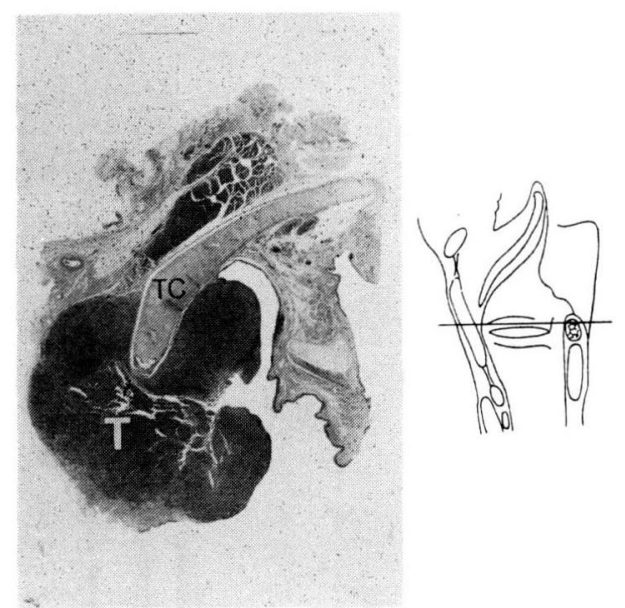

图 8 甲状軟骨迁回外方進展（症例13，×1） $\mathrm{T}$ ：腫煌 TC：甲状軟骨

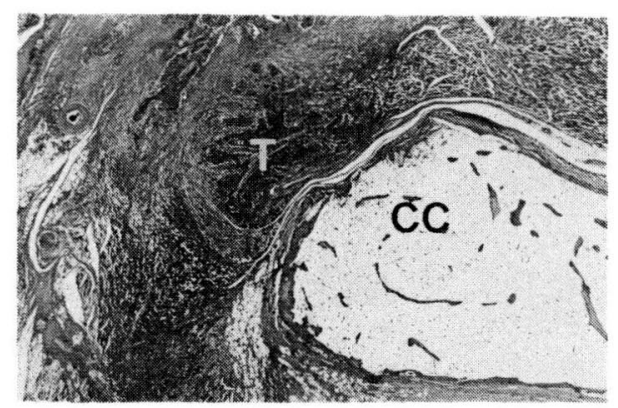

図 9 輪状軟骨への接触（症例16, × 3.3 ) $\mathrm{T}$ ：腫瑒 C C : 輪状軟骨
披裂筋へは接触例 4 例, 浸潤例 5 例の計 9 例に 深達を認めた（図10）.

(4)喉頭蓋軟骨

喉頭蓋軟骨には 8 例 (40\%) で深達がみら れ，挍触例 5 例，浔润例 3 例であった（表 7 ）.

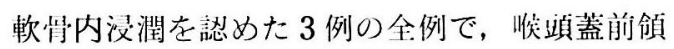
域への腫湟の進展を認めた。一力, 惧触例 5 例 中 2 例で, 腫瘍は軟骨茥部で外方より前内才j 進展し，喉頭蓋前領域に達していた（図11, 12).

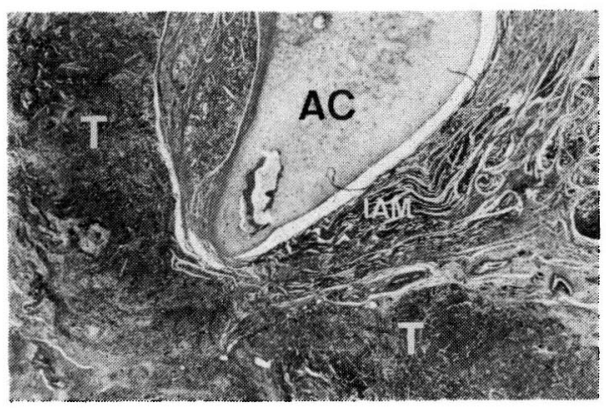

図10披裂軟骨への深達（症例 $14, \times 3.3$ ) 腫汮は披裂軟骨を避けて前内方, 後内方へ進展し ている.

$\mathrm{T}$ : 腫煌 $\mathrm{AC}$ ：披裂軟骨 I AM：披裂筋

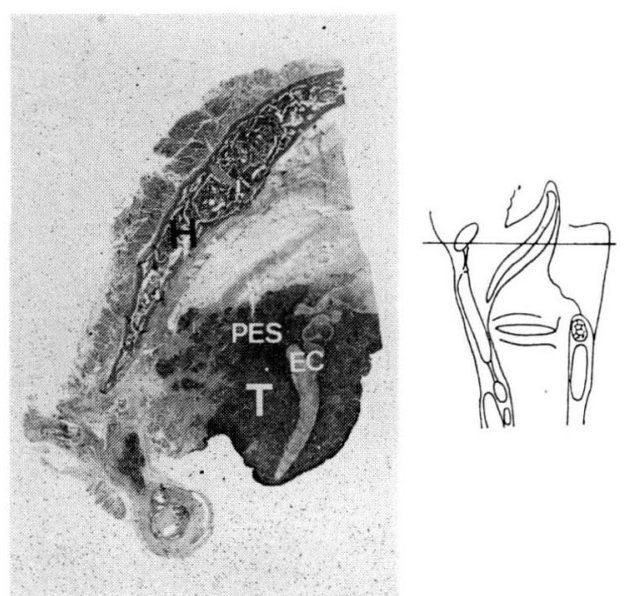

図11喉頭蓋軟骨, 喉頭蓋前領域への深達 (症例 $10, \times 1)$

T：腫煬 EC：喉頭蓋軟骨

P E S : 喉頭盖前領域 $\mathrm{H}$ ：舌骨 


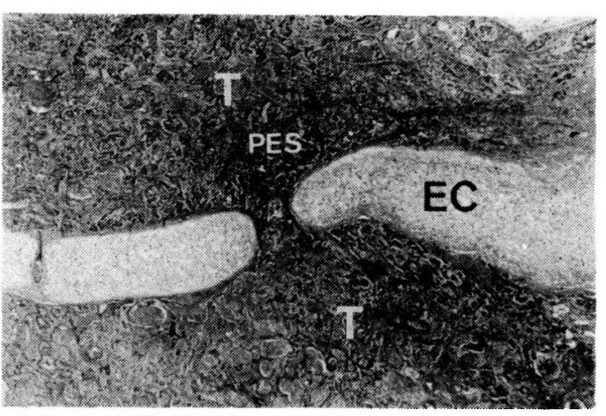

図12喉頭蓋軟骨への深達（症例 $10 ， \times 3.3$ ） 腫焬は軟骨に存在する粘液腺管を貫いて，喉頭蓄 前領域へ進展している.

T：腫焬 P E S : 喉頭蓋㷙領域 E C : 喉頭蓋 軟骨

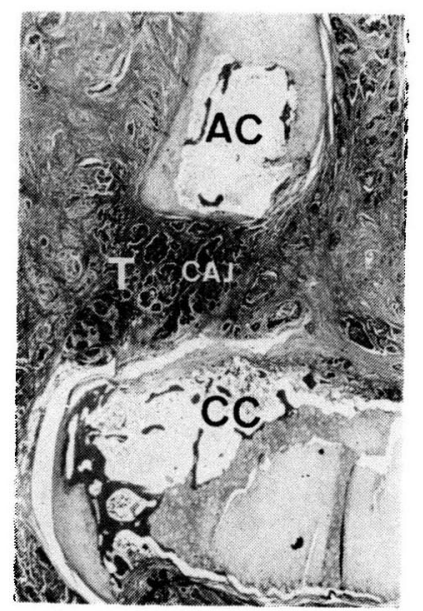

図１3輪状披裂関節への浸潤（症例10，×3.3） T：腫堭 A C : 披裂軟骨 C C : 輪状軟骨 C A J : 輪状披裂関節

\section{2）輪状披裂関節}

輪状披裂関節へは 4 例 $(20 \%)$ で深達を認 め, 接触例 3 例，関節内浸潤例 1 例であった (図13，表 7 ).

3) 内喉頭筋;

(1)甲状披裂筋

甲状披裂筋へは11例（55\%）で深達を認め， 掟触例 2 例，济潤例 9 例であった。

(2)後輪状披裂筋;

後輪状披裂筋八は11例（55\%）で深達を認 め，接触例 5 例，浸潤例 6 例であった（図14）.

(3)外側輪状披裂筋;

外側輪状披裂筋へは11例（55\%）で哚達を認 め, 接触例 5 例，淁潤例 6 例であった。

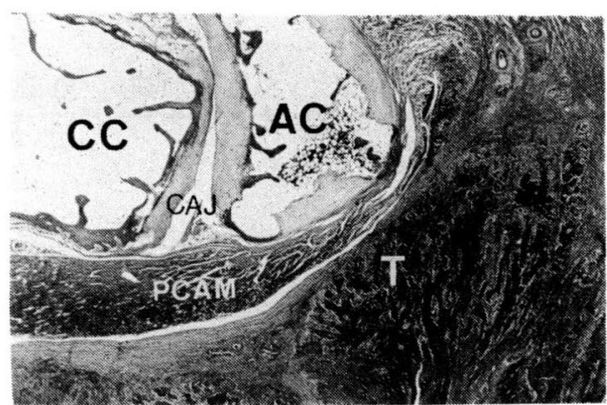

図14後輪状披裂筋への接触（症例 $16 ， \times 3.3$ ） T：腫瑒 A C : 披裂軟骨 C C : 輪状軟骨 C A J ：輪状披裂関節 P C AM：後輪状披裂筋

表 7 喉頭軟骨および輪状披裂関節への深達

\begin{tabular}{|c|c|c|c|c|c|c|c|c|c|c|}
\hline & \multicolumn{10}{|c|}{$\mathrm{T}$} \\
\hline & \multicolumn{2}{|c|}{$\begin{array}{l}\mathrm{T}_{1} \\
(2 \text { 例) }\end{array}$} & \multicolumn{2}{|c|}{$\begin{array}{l}T_{2} \\
(2 \text { 例) }\end{array}$} & \multicolumn{2}{|c|}{$\underset{(12 \text { 例 })}{T_{3}}$} & \multicolumn{2}{|c|}{$\begin{array}{l}\mathrm{T}_{4}^{4} \\
4 \text { 例) }\end{array}$} & \multicolumn{2}{|c|}{$\begin{array}{c}\text { 計 } \\
\text { (20例) }\end{array}$} \\
\hline & 接触 & 浸潤 & 接触 & 浸潤 & 接触 & 浸潤 & 接触 & 浸潤 & 接触 & 浸潤 \\
\hline 軟 学 & & & & & & & & & & \\
\hline 甲状軟骨 & 1 & 1 & 1 & 1 & 8 & 2 & 2 & 2 & 12 & 6 \\
\hline 輪状軟骨 & 0 & 0 & 1 & 0 & 5 & 0 & 2 & 1 & 8 & 1 \\
\hline 披裂軟骨 & 0 & 0 & 0 & 0 & 8 & 0 & 2 & 0 & 10 & 0 \\
\hline 喉頭蓋軟骨 & 0 & 0 & 0 & 0 & 5 & 1 & 0 & 2 & 5 & 3 \\
\hline 輪状披裂関節 & 0 & 0 & 0 & 0 & 2 & 0 & 1 & 1 & 3 & 1 \\
\hline
\end{tabular}




\section{(4)披裂筋}

披裂筋へは11例（55\%）で深達を認め，接触 例 5 例, 浸潤例 6 例であった。

内喉頭筋は，声帯運動を司っている．術前 の患側声帯の運動について検討すると, $\mathrm{T}_{1}$, $\mathrm{T}_{2}$ の計 4 例では良好, $\mathrm{T}_{3}$ の中で 2 例は制限, $\mathrm{T}_{3}$ の 10 例之 $\mathrm{T}_{4} 4$ 例の計 14 例では固定であっ た。内喉頭筋，輪状披裂関節，披裂軟骨への深 達と, 術前の声帯の可動性とを比較した結果が 表 8 である。声带の可動性の良好な 4 例や，可 動性の制限のある 2 例では, 内喉頭筋の一部に 軽度の浸潤が認められるのみで, 輪状披裂関節 や披裂軟骨への深達は認められなかった。可動 性のない14例では，1例（症例 9）では内喉頭 筋の何れにも浸潤を認めなかったが，他の13例 では内喉頭筋の何れかに浸潤を認めた。浸潤さ
れた筋は複数のことが多かった。この13例中 3 例では，披裂軟骨や輪状披裂関節への深達は認 めなかった．残りの10例では披裂軟骨に接触を 認め，またこのうち 3 例では，輪状披裂関節も 接触や浸潤を認めた。

4 ）披裂喉頭蓋ヒダ

披裂喉頭蓋ヒダへは14例（70\%）に深達を認 めた．同部より腫瘍はさらに上内方，上外う， 下内方へそれぞれ進展していた（表 9 ).

5 ) 喉頭蓋前領域

堠頭蓋前領域へは 5 例（25\%）で深達を認め た（表 9 )。披裂喉頚蓋ヒダに腫瘍を認めた 14 例中 8 例では，既述の如く，上内Jの喉頭蓋軟 骨に達し，このうち 5 例は喉頭蓋軟骨を貫通す るか，前内方へ廻り込むようにして喉頭蓋前領 域に進展していた（図11）。

表 8 声帯の可動性と内喉頭筋, 披裂軟骨, 輪状披裂関節への深達

\begin{tabular}{|c|c|c|c|c|c|c|c|c|}
\hline & \multicolumn{8}{|c|}{ 声 } \\
\hline & \multicolumn{2}{|c|}{ (4 例) } & \multicolumn{2}{|c|}{ 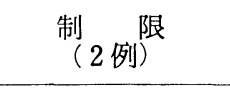 } & \multicolumn{2}{|c|}{ 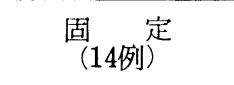 } & \multicolumn{2}{|c|}{ (20例) } \\
\hline & 接触 & 浸潤 & 接触 & 浸潤 & 接触 & 浸潤 & 接触 & 浸潤 \\
\hline \multicolumn{9}{|l|}{ 内喉頭筋 } \\
\hline 甲状披裂筋 & 0 & 0 & 0 & 1 & 2 & 8 & 2 & 9 \\
\hline 後輪状披裂筋 & 1 & 1 & 0 & 0 & 5 & 4 & 6 & 5 \\
\hline 外側輪状披裂筋 & 1 & 0 & 1 & 0 & 3 & 6 & 5 & 6 \\
\hline 披裂筋 & 0 & 0 & 2 & 0 & 3 & 6 & 5 & 6 \\
\hline 披裂軟骨 & 0 & 0 & 0 & 0 & 10 & 0 & 10 & 0 \\
\hline 輪状披裂関節 & 0 & 0 & 0 & 0 & 3 & 1 & 3 & 1 \\
\hline
\end{tabular}

表 9 披裂喉頭蓋七夕゙, 喉頭蓋前領域, 仮声帯, 声帯への深達

\begin{tabular}{|c|c|c|c|c|c|}
\hline & \multicolumn{5}{|c|}{ 類 } \\
\hline & $\begin{array}{l}\mathrm{T}_{1} \\
(2 \text { 例 })\end{array}$ & $\begin{array}{l}\mathrm{T}_{2} \\
(2 \text { 例) }\end{array}$ & $\underset{(12 \text { 例) }}{\mathrm{T}_{3}}$ & $\begin{array}{l}\mathrm{T}_{4}^{4} \\
(4 \text { 例 })\end{array}$ & (20) \\
\hline 披裂喉頭蓋ヒダ & 0 & 1 & 10 & 3 & 14 \\
\hline 喉頭蓋前領域 & 0 & 0 & 3 & 2 & 5 \\
\hline 仮声带 & 0 & 0 & 6 & 2 & 8 \\
\hline 声 帯 & 0 & 0 & 1 & 1 & 2 \\
\hline
\end{tabular}


6 ) 仮声带

仮声帯へは 8 例 $(40 \%)$ で深達を認めた（表 9 ). いずれも披裂喉頭蓋ヒダより，下内方の 喉頭内腔へ粘膜下に進み，仮声带に達したもの であった，仮声带粘膜下には，粘液腺が豊富に 存在するが，この粘液腺が腫瘍の浸潤をうけて 破壊されている例が多くみられた（図15）。

\section{7 ) 声带}

声带八は 2 例（10\%）で深達を認めた（表 9 ).いずれも披裂喉頭蓋七ダから喉頭内腔の 仮声带に進展した腫煌が，さらに下方の声带に 達したもので，披裂軟骨を破壊して直接前内力 の声带へ達するものはみら㧈なかった。

8 ) 咽頭喉頭蓋ヒダ

咽頭喉頭蓋ヒダへは 4 例（20\%）に深達を認 めた（表10）。同部へは，内側の披裂喉頭蓋七 ダより上外方へ進んで達する型と，甲状軟骨内 側面を上方へ進んで達する型がある．4 例中 2 例では両者の進展が認めら扎，また他の 2 例で は，それぞれ前者，後者の進展が認められた。

\section{9 ）甲状舌骨膜}

甲状軟骨の上オで，甲状舌骨膜を貫いて上外 方へ進展する例が 7 例（35\%）認められた（表 10).このうち 6 例は軟骨膜が barrier となっ て，甲状軟骨内側面を上才八進み，抵抗の少な い甲状舌骨膜を破壊したもので，他の 1 例は甲 状軟骨内への高度浸潤例であった。

10）梨状陷以先端部

梨状宿凹先端部を腫瘍が占拠する例は，14例 （70\%）であった（表11）。同部においては， 輪状軟骨と甲状軟骨が接近するため, 腫瘍は内
外より压迫される傾向にあった。

11）気管

梨状陥凹先端部より腫瘍が気管へ深達したの は 3 例（15\%）であった（表11），いずれも気 管壁に按触するものであり（図16），気管軟骨 を破壊したり，膜様部から迴り込むように気管 内へ浸潤するといった例はみられなかった。

(2)甲状腺

甲状腺一の深達は 4 例（20\%）に認めた（表 11）。4例とも甲状腺の被膜に接触するのに留 まり，甲状腺実質内への浸潤例はなかった（図 17)。また 4 例中 2 例は，気管への深達も同時 に認めた。

(3)輪状後部

梨状陥凹先端部から輪状後部八，粘膜上ある

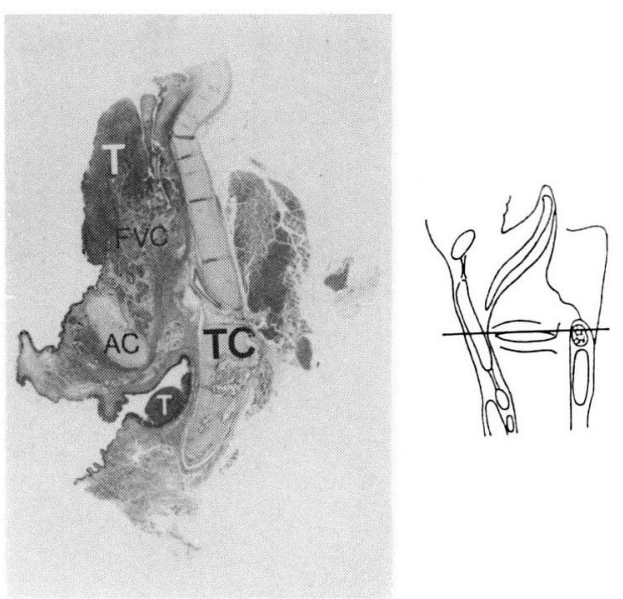

図15 仮声帯への樑達（症例11, × 1)

$\mathrm{T}$ ：腫煬 TC：甲状軟骨 AC：披裂軟骨 F V C : 仮声帯

表10 咽頭喉頭蓋七ダ, 甲状舌骨膜への深達

\begin{tabular}{|c|c|c|c|c|c|}
\hline & \multicolumn{5}{|c|}{$\mathrm{T}$} \\
\hline & $\begin{array}{l}\mathrm{T}_{1} \\
(2 \text { 例 })\end{array}$ & $\begin{array}{l}\mathrm{T}_{2}^{2} \\
\text { ( 例) }\end{array}$ & $\begin{array}{c}\mathrm{T}_{3} \\
(12 \text { 例) }\end{array}$ & $\begin{array}{l}\mathrm{T} 4 \\
(4 \text { 例) }\end{array}$ & $\begin{array}{c}\text { 䛨 } \\
(20 \text { 例 })\end{array}$ \\
\hline 咽頭喉頭蓋ヒダ & 0 & 1 & 3 & 0 & 4 \\
\hline 甲状舌骨膜 & 0 & 1 & 4 & 2 & 7 \\
\hline
\end{tabular}


表II 梨状陥凹先端部, 気管, 甲状腺, 輪状後部, 頸部食道への深達

\begin{tabular}{|c|c|c|c|c|c|c|c|c|c|c|}
\hline & \multicolumn{10}{|c|}{$\mathrm{T}$} \\
\hline & \multicolumn{2}{|c|}{$\begin{array}{l}\mathrm{T}_{1} \\
(2 \text { 例 })\end{array}$} & \multicolumn{2}{|c|}{$\begin{array}{l}\mathrm{T}_{2} \\
(2 \text { 例 })\end{array}$} & \multicolumn{2}{|c|}{$\begin{array}{c}\mathrm{T}_{3} \\
(14 \text { 例) }\end{array}$} & \multicolumn{2}{|c|}{$\begin{array}{l}\mathrm{T}_{4} \\
(4 \text { 例) }\end{array}$} & \multicolumn{2}{|c|}{$\begin{array}{c}\text { 計 } \\
\text { (20例) }\end{array}$} \\
\hline & 接触 & 浸潤 & 接触 & 浸潤 & 接触 & 浸潤 & 接触 & 浸潤 & 接触 & 浸潤 \\
\hline 梨状陷凹先端部 & & 2 & & 2 & & 7 & & 3 & & 14 \\
\hline 気 管 & 1 & 0 & 0 & 0 & 0 & 1 & 0 & 1 & 1 & 2 \\
\hline 甲状腺 & 1 & 0 & 1 & 0 & 1 & 0 & 1 & 0 & 4 & 0 \\
\hline 輪状後部 & & 1 & & 0 & & 2 & & 0 & & 3 \\
\hline 頸部食道 & & 0 & & 0 & & 2 & & 0 & & 2 \\
\hline
\end{tabular}

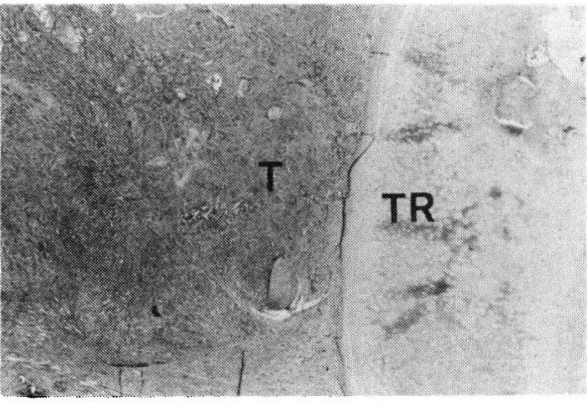

図16 気管への深達（症例 $5, \times 3.3 ）$ T：腫煬 T R：気管軟骨
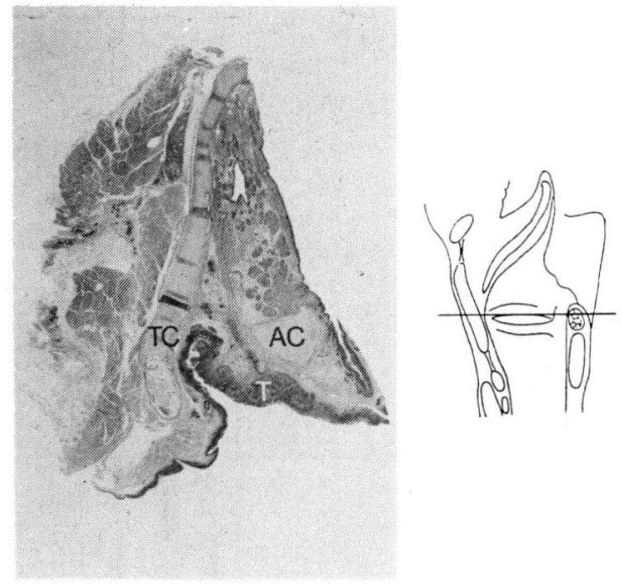

図18表面進展型梨状陷山癌（症例15，×1） T：腫瘍 T C : 甲状軟骨 A C : 披裂軟骨

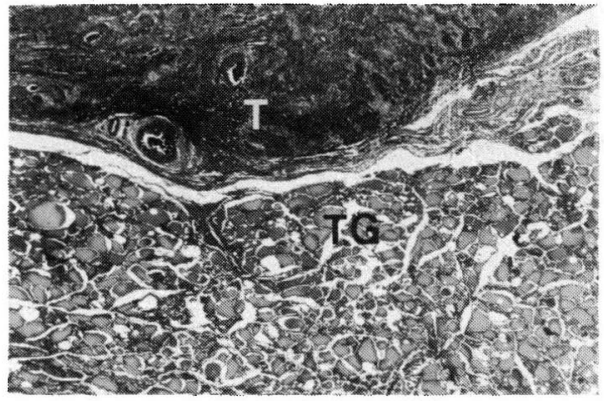

図17甲状腺への深達（症例 $8, \times 3.3$ ) $\mathrm{T}$ ：腫瘍 $\mathrm{T} \mathrm{G}$ ：甲状腺

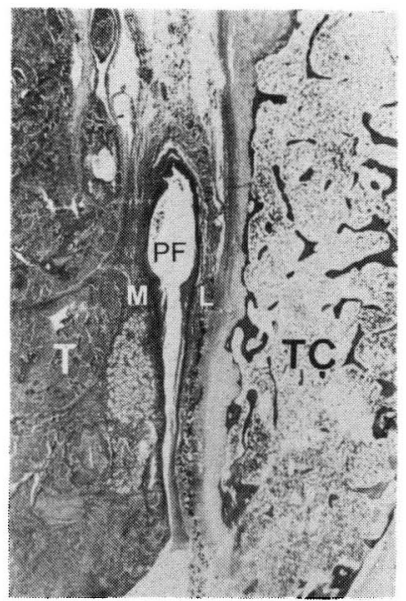

図19梨状陥凹内側原発例（症例10，×3.3） T：腫暘 T C : 甲状軟骨 P F : 梨状陥山 $M$ ：内側 $\mathrm{L}$ : 外側 
いは粘膜下に進展がみられたのは 3 例（15\%） であった（表11）。

(4)钼部食道

梨状陥以から輪状後部に進展した 3 例のうち 2 例 $(10 \%)$ では，さらに下方の頸部食道への 進展がみられた（表11）。1 例は粘膜上での, 他の 1 例は粘膜下での進展であった。

\section{4. 反刘側諸構造物}

正中を越えて反対側への深達を認めたのは， $\mathrm{T}_{3} 3$ 例, $\mathrm{T}_{4} 1$ 例の計 4 例 $(20 \%)$ であった (症例 $5,10,11,16$ )。症例 5 では反対側輸 状軟骨にも接触を認め，披裂筋へ正中を越えて 浸潤していた，聇例10では輪状軟骨，披裂軟常 に接触，喉頭蓋㳄管にも接触を認め，また後輪 状披裂筋，外側輪状披裂筋，披裂筋汇屯㳇潤在 認めた，症例11では喉頭蓋軟骨が正中を越えて 接触していた，症例16では披裂筋こ接触，披裂 㳄骨にも摆触が認められた。4例之も原発部位 は，梨状陥凹の内側壁であった。

5. 表面進展型梨状陷屽癌

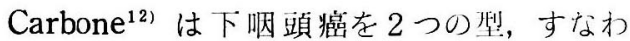
ち深部浸潤型（DIC : Deeply infiltrating carcinoma）と表面進展型（SEC : Superficial

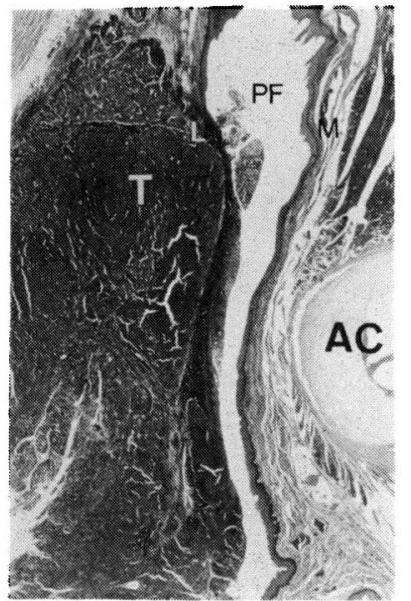

図20梨状陷山外側原発例（症例13， × × .3）

$\mathrm{T}$ ：腫焬 A C : 披裂軟骨 P F : 梨状陌以

$\mathrm{M}$ ：内側 $\mathrm{L}$ ：外側 extending carcinoma) とに分類している。 こで本研先での自験例20例について分類してみ た所，D I C19例，S E C 1 例（症例15）であ った，症例15では，腫焬は粘膜面を平面的に执 がり，軽度の粘膜下浸潤を認めるむのの，樑部 への浸潤は一部分で認めただけであった（図 $18)$.

\section{6.腫瘍の原発部位之進展度}

腫瘍の内方進展が外方進展より著しいため, 原発部位が梨状陷川の内側壁と考えられた症例 は 7 例であり，また外方進展の乃が著しく，原 発部位が外側壁と考えられた症例は 4 例であっ た（図19，20）。進展が内方，外方共に著し く，原発部估が内側壁か外側壁かが不明であっ た症例は 9 例であった。原発部位之進展度を此 較したのが表12である。

外側壁原発例 4 例の $\mathrm{T}$ 分類に上る内分けは, $\mathrm{T}_{2} 2$ 例， $\mathrm{T}_{4} 2$ 例で $\mathrm{T}_{3}$ はみられなかった。 $\mathrm{T}_{2}$ u） 2 例では，外方進展で甲状軟骨に挍触あるい は浸潤が生:じていたが，内方進展は軽度で，内 喉㖽筋の一部に接触を認めるのみであった。

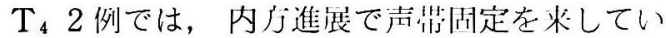

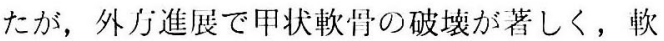

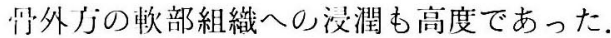

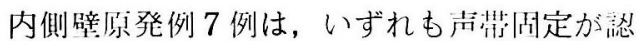
められた（ $\left.\mathrm{T}_{3}\right)$ ）この中で 4 例では，正中を越 えて反対側にも深達が及んでいた。 また 3 例で は，外方進展で甲状軟器外广への，進展がみられ た。

7。粘膜下進展度

扁平上艾癌18例に抢いて，腫瘍の咽䫓側およ び食道侧で，粘謨卜進展距離を計测した。咽䫓 侧では最人 $16 \mathrm{~mm}$ ，斗均 $7.2 \mathrm{~mm}$ ，位道側では最大 $14 \mathrm{~mm}$ ，半均 $5.8 \mathrm{~mm}$ の粘膜下進展を認めた（表 13）。栶韻側での粘傥下進展のうがより高度で あった。

\section{8. 脈管侵襲}

脈管侵熋は，甬平上:波癌18例中10例之高率に 垫められた（図21）。粘膜卜進展度と脈管侵襲 との関係について検㣙した絬果が表14である。 
粘膜下進展距離が咽頭側あるいは食道側で $10 \mathrm{~mm}$ 認めた.

以上認めた 7 症例の中では， 6 例に脈管侵襲を

考

喉頭癌の連続大切片標本による臨床病理学的 研究は, 現在まで内外で多数の報告があり, 進 展様式, 臨床所見と病理組織学的所見とり関係 などが, 明らかにされつつある。しかし下咽頭 癌に関しては, 喉頭癌に較べ症例数が少ないこ

\section{按}

とや，腫瘍の進展が広範で切片が大きくなるな どの不利な点があることから，乙れまで連続大 切片による臨床病理組織学的研究はあまりなさ れていない，欧米では Kirchner ${ }^{9)}$ が51症例の 連続大切片を作製し報告している他，Harri-

表12 原発部位と進展方向

\begin{tabular}{|c|c|c|c|c|c|c|}
\hline \multirow{3}{*}{ 進展方向 } & \multicolumn{4}{|c|}{ 外側壁原発（4 例） } & \multirow{2}{*}{\multicolumn{2}{|c|}{$\frac{\text { 内側壁原発（7 例） }}{\mathrm{T}_{3}(7 \text { 例 })}$}} \\
\hline & \multicolumn{2}{|c|}{$\mathrm{T}_{2}$ （2 例） } & \multicolumn{2}{|c|}{$\mathrm{T}_{4}$ (2 例) } & & \\
\hline & 接触 & 浸潤 & 接触 & 浸潤 & 接触 & 浸潤 \\
\hline $\begin{array}{l}\text { （外 方）甲状軟骨 } \\
\text { (甲状軟骨外方) }\end{array}$ & 1 & $\begin{array}{c}1 \\
(1)\end{array}$ & 0 & $\begin{array}{c}2 \\
(2)\end{array}$ & 5 & $\begin{array}{c}0 \\
(3)\end{array}$ \\
\hline （上外方）甲状舌骨膜 & 0 & 1 & 0 & 1 & 0 & 1 \\
\hline （内 方）披裂軟骨 & 0 & 0 & 1 & 0 & 6 & 0 \\
\hline 甲状披裂笳 & 0 & 0 & 0 & 1 & 0 & 5 \\
\hline 後輪状披裂筋 & 1 & 0 & 2 & 0 & 1 & 3 \\
\hline 外側輪状披裂筋 & 1 & 0 & 1 & 1 & 1 & 3 \\
\hline 披裂筋 & 0 & 0 & 1 & 0 & 2 & 4 \\
\hline （上内方）披裂喉頭蓋ヒダ & & 1 & & 1 & & 6 \\
\hline
\end{tabular}

表I3 粘膜下進展度（扁平上皮癌18例）

\begin{tabular}{l|c|c}
\hline & 最 大 (mm) & 平 均 $(\mathrm{mm})$ \\
\hline 咽 頭 側 & 16 & 7.2 \\
食 道 側 & 14 & 5.8
\end{tabular}

表14 扁平上皮癌における 脈管浸襲と粘膜下進屡度

\begin{tabular}{rl|c|c}
\hline \multirow{2}{*}{ 脈管侵襲 } & \multicolumn{2}{|c}{ 粘膜下進展度 } \\
\cline { 3 - 4 } & $<10 \mathrm{~mm}$ & $\geqq 10 \mathrm{~mm}$ \\
\hline あ & り & 4 & 6 \\
な & し & 7 & 1
\end{tabular}

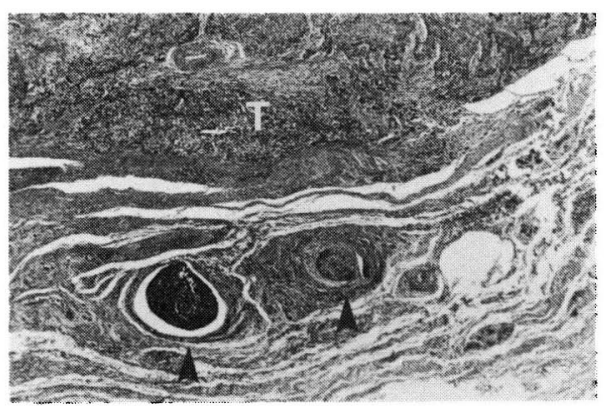

図21 脈管侵襲（症例14, $\times 13.2$ ) 矢印に脈管侵襲を示す. $\mathrm{T}$ ：腫場 
son $^{11)}$ の破㪇があるが，乙れら以外には，下汌 頭癌に焦点を絞った研究はみあたらず，Olofsson $^{8)}$ が29例, Ogura ${ }^{10)}$ が16例り下咽頭癌に ついて，その喉頭癌での研究り中で言及してい る程度である。国内での報告はさらに少なく， 特に下咽頭癌手進展範囲，進展方向に関する研 宄は皆無である。

下㕧韻の中で，梨状陷川に原発する癌は，最 む頻度が高い。また進展範囲が輪状後部げ一珚頭 後壁に原発する癌とは異なるため，治療法も異 なってくる。乙れらう点に留意し，今回著者は 梨状陷川癌について，大切片槽本を用いた病理 組織学的研究を行ない，前述のような成績を得 た。

\section{1. 腫瘍の組織型について}

下咽韻癌の組織型は, 他の䫓頸部領域の癌と 同様，扁平上皮癌が压倒的に多い。今回の検索 対象となった20例において屯，18例（90\%）が 扁平上波癌であった。他の 2 例 $(10 \%)$ は, 癌 腫之肉腫の混在する癌肉腫であった。癌肉腫の 2 例は， $\mathrm{T}$ 分類ではいずれも $\mathrm{T} 4$ であることか ら, 癌肉腫の方が扁平上波癌より腫瘍の増大が 急速であることが推察される。

\section{2. 腫瘍の組織学的悪性度について}

屏米上皮癌18例について, Willén の分類に 基づき腫瘍の組織学的悪性度を検討した結果, 腫瘍汶潤の程度が強いことが特徵的であった。 しかし悪性度点数は $8 \sim 12$ 点で一応に高くな く,この方法で悪性度の個体差を評価すること は困難であった。

3. 腫崵の諸棈造物への進展について

腫瘍つ各構造物八の深達につき検欱した結果 は, 砸焱結果の項で述べた。しかし, 本研究の 主たる日的は, 腫瘍の進展的向, 進展範囲, 進 限様式を明らかにするととである。従って本項 では，まず腫瘍つ吹骨への進展について考察を 版えた後，砸坣結果をむとに進展少向を外方， 内广，上内广，上外方，下方に分け，それぞれ の進展方向に基づいて, 進展範囲, 進展椂式を 再構築しながら述べるとととする。

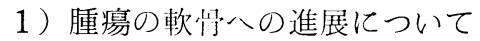

腫瘍の㳄骨への進屡は, 腫瘍が軟骨膜まで達 するが，欶骨膜が barrier となって軟骨内一 の浸潤がみられない接触例と, 軟骨膜を破壊し 軟骨内一、浸潤する浸潤例とに分類される。

聅䫓軟骨の内, 甲状軟骨, 輪状軟骨, 披裂軟 骨は硝子軟悄であり，此較的硬く腫瘍に対して 抵抗性を示すため, 浸潤例より接触例の方が多 かった。

軟骨内浸潤は, 目験例では甲状軟骨 6 例, 輪 状軟骨 1 例の計 7 例に認めたが, 全例が軟骨の 化骨部位で生じていた。堠頭軟骨は加令と共に 化骨化するが，その化骨は甲状軟骨では下角か ら始まり，後縁を頭側へ，下縁を前方へ進み， また輪状軟骨では頭側から始まるといわれてい $ろ^{21)}$. そして Olszewski ${ }^{20)}$, 竹田 ${ }^{27)}$, 佐藤 ${ }^{32)}$ らによれば, 癌による喉頭軟骨の破壊は化骨部 から始まり，その理由として，化骨部血管孔の 存在と脂肪骨髅の発達を挙げている。すなわち 化骨部血管孔から癌細胞が侵入し, 脂肪骨髄中 を急速に進展するためであるという。自験例の 検討から, 梨状陷凹癌における軟骨内浸潤も同 様の機序で生じ, 甲状軟骨後縁や下縁, 輪状軟 骨上端に好発すると考えられた（図6）。

2 ) 腫瘍の進展方向と進展範囲, 進展様式に ついて

(1)外方進展

研究の結果より, 腫瘍が外方へ進展すると, 容罗に甲状軟骨八深達することがわかる。軟骨 膜に達した腫瘍の態度は，2つの型に分類でき る。1つは軟骨膜を破壊し軟骨内へ浸潤し，さ らには外側の軟骨膜を屯破壊して軟部組織へ進 展する型で，他の 1 つは甲状軟骨の後方へ过回 し軟部組織へ進展し，同時に甲状軟骨内縁を上 行する型である。

Kirchner ${ }^{9)}$ は51例中22例 (43\%), Olofsson ${ }^{8)}$ は19例中 8 例 $(42 \%)$ に甲状軟骨内浸潤を諗 めたと報告している。自験例では浸潤例は 6 例 (30\%) で，てのうち5 例が前者の進展様式で 軟骨外方の軟部組織に進展していた。一方後者 
の進展様式をとったものは 8 例で, 頻度として は後者の广が多かった。いずれかの様式で軟们 外广jの軟部組織一進展した例は13例（65\%）之 高率であり，甲状軟骨は腫瘍の外方進展に対し て十分な barrier となっていないことが判明 した（図22-a，b).

(2)内少進展と藏带周定について

腫瘍が内广進展で披裂軟骨に達してむ，!験 例では軟骨内一浸潤する例はなく（表 6 ），腫

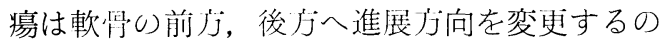
が観察された。すなわち，言い換えれば披裂軟

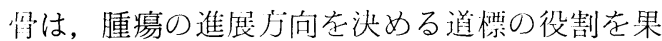
たしているといえる。声門レベルで前内方への 樑達の程度が後内方に較べて強いのは，披裂軟 䈰の形状と関係が深いと思われた。また腫瘍り 進展广向上筋の走行肪，甲状披裂筋では南角に 近く，後輪状披裂筋では平行に近いため，腫瘍 の筋尿内浸潤は，筋膜が barrier 之成り難い用 状披裂筋により多く生じるものと考えられた。

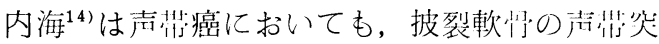
起部まで浸潤してきた癌胞巣が，乙てから下j と上少へ進展主力方向を変えると述べている。 このととから披裂軟訬は，嘫頭癌に沏いても下 咽韻癌においても，腫瘍の進展分向を規定する のに重姦な役制りを果たすといえる（図23）。

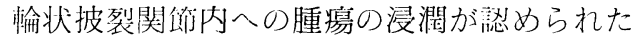
のは 1 例だけであった。披裂軟骨を避けて後内 方に進展する腫瘍は，後輪状披裂筋や外側輪状 披裂筋に浻って進む傾向にあり，乙れらの筋群 が関節への腫瘍の深達に対して barrier とな っていると考えられる。

輪状軟算屯浸潤例は 1 例のみで，腫瘍の内' $j$ 進展に対して，強い抵抗性を示すと考えられ た。

梨状陷川癌の内户進展で，声䵎同定がしばしば

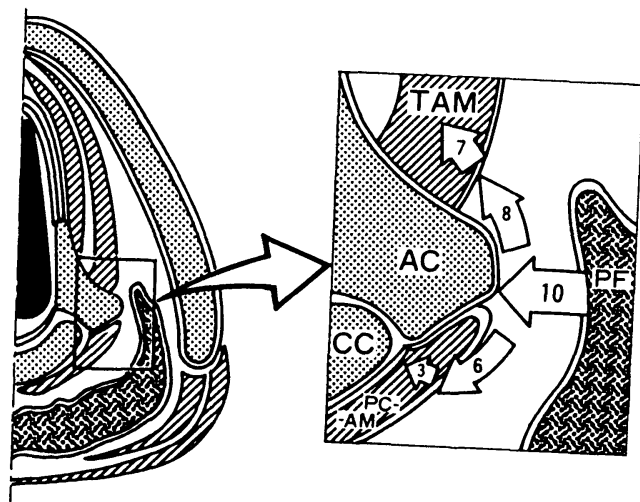

図23披裂軟骨への深達之内喉頭筋への浸潤 P F : 梨状陥凹 A C : 披裂軟骨 C C : 輪状軟骨 T AM：甲状披裂筋 P C AM：後輪状披裂筋
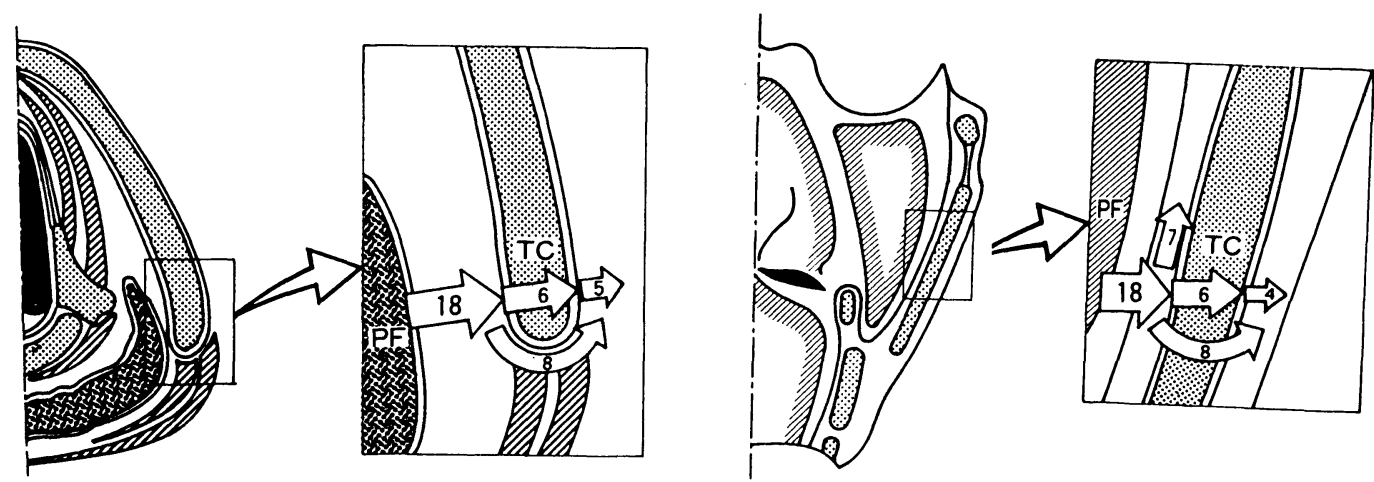

図22 甲状軟骨およびその外方への進展 P F：梨状宿凹 
起こる。その原因としては, 従米

(1)後輪状披裂筋八の浸潤

(2)輪状披裂関節への浸潤

(3)反回神経への浸潤

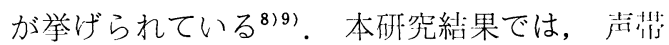
固定を認めた14例の中で，内喉頭筋のいずれに も全く浸潤を認めなかったのは，わずか 1 例の みであった。この例における声渜固定の発現機 序は, 反回神経麻痺によるものと考えられた。 一方他の 13 例では, 内喉頭筋のうちのいずれか に浸潤が認められた。多くの例では浸潤をうけ た筋は複数であった。さて，上記の13例中，輪 状披裂関節に浸潤を認めたのはたった 1 例のみ

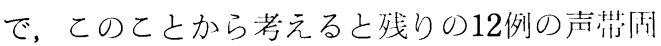
定は，内喉頭筋への浸潤により生じるものと考 えられる。 この12例で, 腫瘍が内喉頭筋のうち どの筋へ深達しているのかを検討すると, 声門 開大筋である後輪状披裂筋への深達を認めなか った症例は，4 例であった。 4 例中 2 例では， 甲状披裂筋にのみ樑達を認め, 他の 2 例では, 甲状披裂筋之披裂筋に深達老認めた。一方他の

8 例では, 後輪状披裂筋への深達を認めたが,

8 例全例で, 声門閉鎖筋である甲状披裂筋, 外 側輪状披裂筋，披裂筋のいずれかに深達を誌め た。この結果加ら考えると, 内聅頭筋八の浸潤 により声带固定が生じる場合，その原因は，

Kirchner $^{9}$ や Olofsson ${ }^{8)}$ が述べているよう に，声門開大筋である後輪状披裂䈈八の腫瘍の

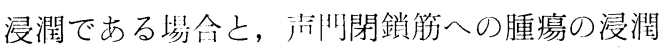

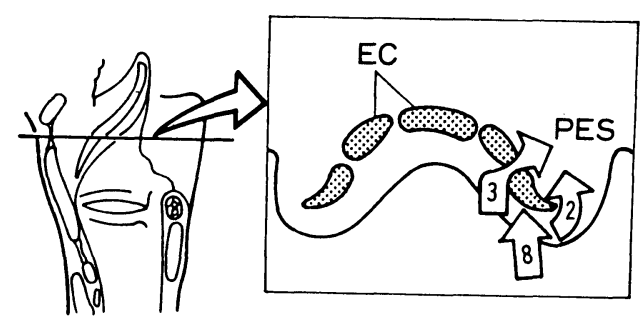

図24喉頭蓋軟骨および喉頭蓋前領域への進展 E C：喉頭蓋軟骨 P E S：喉頭蓋前領域
である埸命があることが明らかとなった。披裂 軟骨に達した腫瘍が，前内方のみに進展し，甲 状披裂筋へ浸潤した症例でも，声州䦌定は生じ ていた。このような例では，村上 ${ }^{28)}$ が述べてい るように mass-effect が声带固定に関与して いる可能性が示唆される。以上の事から梨状陥

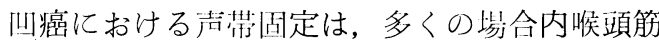
が浸潤をうけることによって生じるあのであ り，乙の場合，浸潤が高度となり輪状披裂関節 が浸潤をうける場合もあるが，その頻度は少な く，それ以前に内薙頭筋が浸潤をうけることに より，声带固定は完成しているもの之考えられ る.

腫瘍が内方進展で正中を越えて反刘側八進展 していたのは 4 例で，乙れらはいずれあ内側壁 原発の症例であった。 Ogura ${ }^{10)}$ も同様の結果 を報告している。

(3) 上内方進展

上内方進展は披裂喉頭蓋七ダを基点とし，一 方では，さらに上内方の喉頭蓋から㘈頭蓋前領 域や，上外方の咽頭喉頭蓋七ダへ進展する。喉 頭蓋軟骨は，その茎部を粘液腺の腺管が貫通し ているため，乙れを通じて腫瘍は，比較的容多 に北頭蓋前領域に進展する ${ }^{4) 532)}$ 。また形状が 菱形であるため, 基部では外側から廻り込むよ うにして，喉頭蓋前領域に進展しやすく，乙れ らのことから㗹頭蓋軟骨は，腫瘍に対してあま り抵抗性がないといえる（図24）。

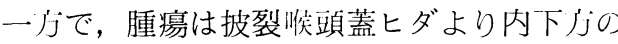
喉湏内腔へ進展する。喉頭のリンパ流は，吉 井 ${ }^{22}$ によれば，仮声㴖之声带を境とし，仮声率 より上方は上行性に流机る。こうしたリンパ流 から考える之，披裂喉頭盖七ダより下内户人の

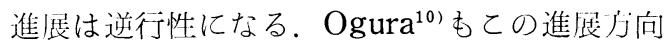
を“retrograde” と表现している。このよう な逆行性の進展について, Deka ${ }^{4)}$ は粘液腺管 系が重要な役制りを果たすと述べている。すな わち，下咽頭癌は，披裂部占披裂喉頭蓋七ダか ら唯頭内腔へ粘膜下で “g randular route” より進展するという。本研究結果でも, 仮声嬊 
の粘膜下で，粘液腺が腫瘍の浸潤をうけている ことが多く認められ，このととが示唆された。 上内方への進展は，腫瘍に対する barrier の 火如のため広範囲にわたる（図25）。

(4) 上外方進展

腫瘍が外側で上うう進展すれば，咽頭喉頭蓋 ヒダより中咽頭に達する。しかし，ここに至る までに，甲状軟骨に压迫された腫湢は，抵抗の 弱い甲状舌骨膜を貫いて上外方へ進展すること が多い、また喉頭よりのリンパ管がこの膜を貫 くため，脈管侵襲も腫瘍の進展に関与している と思われ，同部での外方進展は下部に較べてよ り広範となる例が多い（図26）。

\section{(5)下方進展}

腫瘍が梨状陷川先端部をら拠することは，少 なからず認められる。しかし，同部は内方の輪 状軟骨と外方の甲状軟骨が近接しているため， 腫瘍は内外から压迫をうけ，同部より下方へ䉼 膜に沿って進展することは比較的少ない。験 例では，頸部食道へは 2 例に進㪯を認めたが， Kirchner ${ }^{9)}$ は51例中 1 例も認めなかったと報

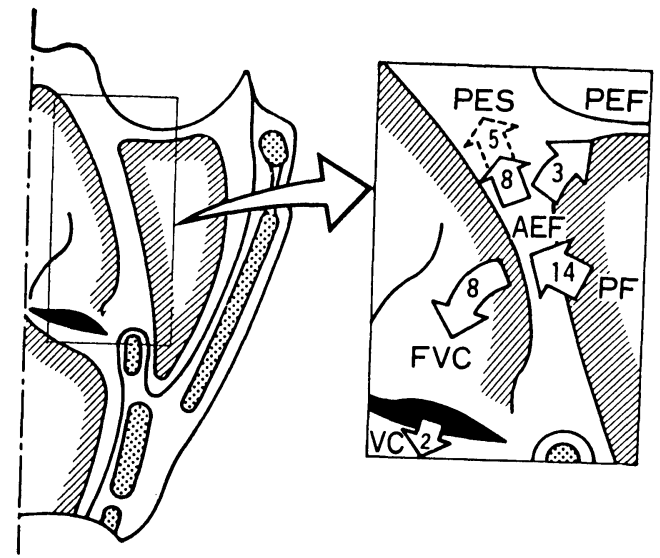

図25披裂喉頭蓋七ダを中心とする上内方進展 PF：梨状陷凹 A E F : 披裂喉頭蓋ヒダ P E S : 喉頭蓋前領域 P E F：咽頭喉頭蓋七ダ FVC：仮声帯 VC：声帯
台している.

しかし，一う梨状陷凹先端部より粘膜下で気 管や甲状腺に深達が及ぶ例があることは, 念頭 におく必要がある。すなわち，Ogura ${ }^{10)}$ は16 例中 2 例に甲状腺被膜に，Olofsson ${ }^{8}$ は19例 中 2 例に甲状腺に，1例に気管に腫瘍の浸潤を 認めている。白験例でも，甲状腺被膜へは 4 例，気管へは 3 例で深達を認めた（図27）.

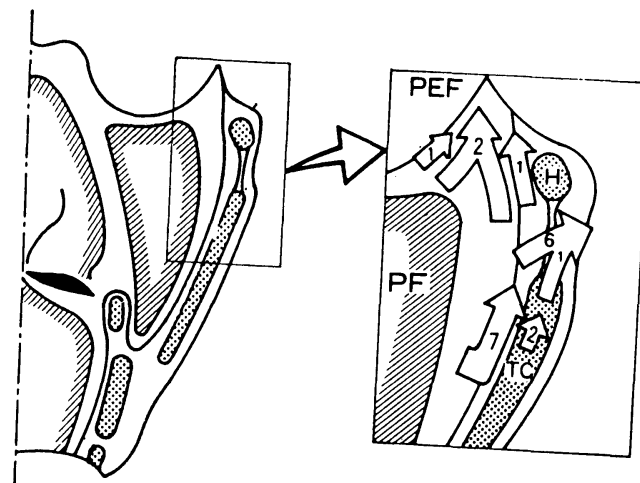

図26咽頭喉頭蓋ヒダおよび甲状舌骨膜外方への
進展

P F : 梨状陷山 $\mathrm{H}$ ：舌骨 $\mathrm{T} \mathrm{C}$ ：甲状軟骨

P E F：咽頭喉頭蓋ヒダ

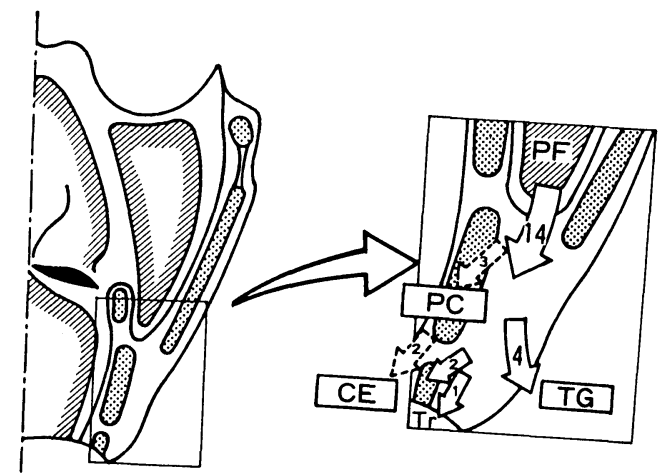

図27梨状陥凹先端部より下方への進展 P F：梨状陥凹 $T G$ ：甲状腺 $T r$ ：気管 P C : 輪状後部 C E : 頸部食道 
4. 反対側構造物への進展について

反対側へ正中を越えて進展を認めたのは 4 例 で，いずれむ梨状陥凹の内側壁原発症例であっ た。腫瘍が増大すれば，前内方で喉頭蓋軟骨を 貫いて，あるいは後方で披裂筋に浴うように， 反対側へ腫瘍が進展するといえる。

5. 表面進展型梨状陷凹癌について

Carbone の述べている初期粘膜下浸潤を伴 なうS E Cを 1 例に認めた。彼の検討では 242 例の下咽頭癌の中で, 純粋に粘膜内に留まる $\mathrm{S}$ E C 7 例, 初期粘膜下浸潤在供うS E C 15例, S E CとD I Cが混在するもの 4 例を認めてい る。 S E Cから D I Cへ移行する部分があるて とから S E C は D I Cの初期段階であろうと考 えられる。

6. 原発部位と進展度

Ogura ${ }^{10)}$ は原発部位を内側壁, 外側壁, 先 端に分類することは，実際あまり有用でないと 述べている。しかし自験例においては，内側壁 に原発するものと外側壁に原発するものでは， 内方および外方への進展範囲に差を認めた。外 側壁原発の 4 例の $\mathrm{T}$ 分類による内分けは, $\mathrm{T}_{2}$ 2 例， $\mathrm{T}_{4} 2$ 例で， $\mathrm{T}_{3}$ はみられなかった。 $\mathrm{T}_{4}$ の 2 例では, 甲状軟骨外方の軟部組織への進展走 認め, さらに $\mathrm{T}_{2}$ の 2 例中 1 例でも, 摘出慓本 では甲状軟骨外方への淮展を認めた。このとと から考えると, 外側壁原発では内側壁原発に較 ベて，より外方へ進展しやすく， $\mathrm{T}_{2}$ から声率
闻定を生じる（ $\mathrm{T}_{3} ）$ 前に $\mathrm{T}_{4}$ になる可能性があ るといえる。一う内側壁原発では 7 例とも声州 周定が認められ $\mathrm{T}_{3}$ であった。従って内側壁原 発では，腫瘍発現後比較的迅汃に $\mathrm{T}_{3}$ になる可 能性がある。乙れらのことは T分類上問題を残 すと思われた。

7. 粘膜下進展度について

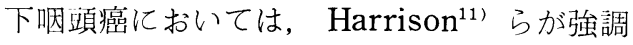
している如く癌の粘膜下進展が広範であり，乙 のととが腫愓摘出に際し重要な問題となる。粘 膜下進展を見逃せば, 局所再発の原因となるか らである。木村 ${ }^{18)}$ は下咽頭頸部食道癌の粘膜下 進展距離を計测し, 咽頭側は最大 $19 \mathrm{~mm}$, 平均 $10.8 \mathrm{~mm}$, 传道側は最大 $10 \mathrm{~mm}$, 平均 $5.2 \mathrm{~mm}$ 之報告 している。梨状陷凹癌における自験例の結果で は, 咽頭側は最大 $16 \mathrm{~mm}$, 平均 $7.2 \mathrm{~mm}$, 食道側で は最大 $14 \mathrm{~mm}$, 平均 $5.8 \mathrm{~mm}$ であった。乙れらは郘 定噤本に抢ける計測值であることを考慮する と, 手術に際しての腫演の切離線は, 咽頭側, 食道側之屯，腫瘍の粘膜面断端より少なくとも $2 \mathrm{~cm}$ 離れた部位におくべきであると考えられ た.

\section{8. 脈管侵襲について}

Olofsson は，19例中 2 例に脈管侵襲を認め ているが，自験例では10例（50\%）と高率に認 めた。脈管侵襲は, 梨状陷叮癌の粘膜下進展に 大きな役制りを果たしていることが推察され た.

語

梨状陥山癌の術前非照射例20例の摘出愫本を用いて大切片椣本を作製し，病理組織学的進展度に ついて検討した結果，次のような結論を得た。

1. 将頭軟骨への深達は, 接触例と浸潤例に分類され, 浸潤は軟骨の化骨部位におこる。

2.腫瘍の甲状軟骨外方の軟部組織への焦展様式は，甲状軟骨を浸潤破流する型と軟骨を迁回す る型があり，甲状軟骨は腫演の外方進展に対して十分な barrierとはならない.

3. 腫瘍の内方進展に打いて, 披裂軟骨は進展方向を決める道慓の役制りを果たしており，軟骨 に達した腫瘍は，その進展方向を前内方，後内方一と変更する。

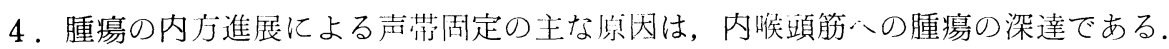

5。腫瘍は披裂喉頭蓋七ダより上方で，広範な粘膜下進展を示すことが多く，また同部より喉頭 内腔への逆行性の進展には，粘液腺管系が関与していることが示唆される. 
6. 腫湯の下方進展は，上方に較べ軽度であるが，頸部食道への進展は 20 例中 2 例にみられ，ま た粘膜下で甲状腺や気管へ深達する例があることに留意すべきである.

7. 梨状陥四の内側壁原発之外側壁原発では，内，外方への進展範囲に差がある。外側壁原発で は甲状軟骨外方へ進展しやすく， $\mathrm{T}_{2}$ から $\mathrm{T}_{3}$ を経ずに $\mathrm{T}_{4}$ になる可能性があり，一方内側壁原発 では，内方進展で声带固定が生じやすく $\mathrm{T}_{1}$ から $\mathrm{T}_{2}$ を経ずに $\mathrm{T}_{3}$ になる可能性がある.

8，粘膜下進展を考慮すると，腫湯摘出に際しては，咽頭側，食道側とも，粘膜面での腫瘍断端 より少なくとも $2 \mathrm{~cm}$ 離して, 腫愓を切離すべきである.

謝辞

終稿伤み，御校閲頂いた服部 浩教授に感謝の意を表します。また病理組織学的研究亿ついて終始御指導を 頂いた兵庫県立成人病センタ一検查部病理指方輝正博士に感謝いたします。なお，本論文の要旨は第 8 回日本頭 頻部腫瑒学会において発表した。

文

1) Tucker G: A histological method for the study of the spread of carcinoma within the larynx. Ann Otol Rhinol Laryngol 70 : 910 921, 1961.

2) Tucker G: Some clinical inferences from the study of serial laryngeal sections. Laryngoscope $73: 728 \sim 748,1963$.

3) Kirchner JA: Two hundred laryngeal cancers: Patterns of growth and spread as seen in serial section. Laryngoscope 87 : 473 482, 1977.

4) Deka RC, Kacker SK, Roy S, et al : Glandular theory of cancer spread in the larynx. Indian J Otolaryngol 28: 115 117, 1976.

5) Delahunty JE and Nassar VH: Application of total organ laryngeal section. Arch Otolaryngol $90: 342 \sim 346,1969$.

6 ) Deka RC: Clinical and whole organ section studies on cancer of the larynx and laryngopharynx. Indian J Otolaryngol $27: 7 \sim 25$, 1975.

7 ) Eisbach KJ and Krause C J : Carcinoma of the piriform sinus $-A$ comparison of treatment modalities. Laryngoscope $87: 1904 \sim 1910$, 1977.

8) Olofsson J and Nostrand AWP : Growth and spread of laryngeal and hypopharyngeal carcinoma with reflections on the effect

\section{献}

of preoperative irradiation. Acta Otolaryngol 〔Supp1] $308: 1 \sim 84,1973$.

9) Kirchner JA : Piriform sinus cancer : A clinical and laboratory study. Ann Otol Rhinol Laryngol $84:$ 793 803, 1975.

10) Ogura JH : Surgical pathology of cancer of the larynx. Laryngoscope $65: 867 \sim 926$, 1955.

11) Harrison DFN : Pathology of hypopharyngeal cancer in relation to surgical management. J Laryngol Otol $84: 349 \sim 367,1970$.

12) Carbone A, Michean C, Bosq J, et al: Superficial extending carcinoma of the hypopharynx : Report of 26 cases of an underestimated carcinoma. Laryngoscope $93: 1600$ $\sim 1606,1983$.

13）江浦睦重：喉頭癌の組織学的及び臨床病理学的研 究. 福岡医学雑誌 $47: 265 \sim 295,1956$.

14）内海重光：声帯癌の進展型式とその臨床病理学的 研究. 日耳鼻 $73: 1488 \sim 1505,1970$.

15）尾崎正義：喉頭癌の病理組織学的研究一とくに披 裂軟骨・輪状披裂関節をめぐる病变について一. 日耳鼾 $83: 164 \sim 177,1980$.

16）高田研太：喉頭癌における臨床所見之病理学的進 展との関連について. 耳展 26:701〜712, 1983.

17）山田篤伸：段階的大切片標本による喉頭癌の臨床 病理組織学的研究. 耳鼻 $26: 375 \sim 392,1980$.

18）木村利貞：下咽頭頸部食道癌の臨床的並びに病理 
組織学的研究. 耳鼻臨床 $54 ： 267 \sim 282 ， 1961$.

19）中島重隆: 大切片標本による喉頭癌の病理組織学 的研究. 日耳鼻 $69: 1 \sim 53,1966$.

20) Olszewski E : Vascularization of ossified cartilage and spread of cancer in the larynx. Arch Otolaryngol 102:200 203, 1976.

21) Pontaja E: The laryngeal cartilages. Arch Otolaryngol $87: 416 \sim 421,1968$.

22）吉井 功：耳鼻咽喉科領域におけるリンパ流の臨 床的研究. 日耳鼻 $67: 886 \sim 914,1964$.

23）平野 実, 進 武幹, 三橋重信, 市川昭則, 三橋 勝彦，他：教室における下咽頭頸部食道癌の遠隔 成績. 耳鼻 $22: 737 \sim 747 ， 1975$.

24）村上 泰, 大塚 護, 行木英生, 堀内正敏, 浅岡 一之，他：下咽頭・頸部食道癌に対する治療方針 とその成績一過去 5 年間の一次治療例, 42 症例の まとめ一. 日気食 $28: 364 \sim 379,1977$.

25）天津蒦郎，松居敏夫，牧 孝，深沢高士，金川 清人, 他：下咽頭頸部食道癌の治療法とその成績 一手術的治燎を中心として一. 耳鼻臨床 75 ： 641 650, 1982.

26) Willén R, Nathanson A, Moberger G, et al : Squamous cell carcinoma of the gingiva.
Acta Otolaryngol $79: 146 \sim 154,1975$.

27）竹田千里：㩔頭癌の発育と進展方向に関する臨床

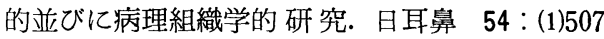
$\sim 514$ ，(2)553〜561， 1951.

28）村上 泰：下咽頭部分切除術. 日耳鼻 $82 ： 289$ 295, 1979.

29) Krespi YP, Sisson GA : Voice preservation in piriform sinus carcinoma by hemicricolaryngopharyngectomy. Ann Otol Rhinol Laryngol $93: 306 \sim 310,1984$.

30）村上 泰, 猪狩武詔, 原口茂德, 岡田康司, 安藤 真姿子, 他: 下咽頭癌治療に関する総合的研究. 日耳鼻 $85 ： 1310 \sim 1311.1982$.

31）沢木修二：喉頭癌における披裂部病変に関する臨 床的並びに病理組織学的研究. 日耳鼻 $62: 1347$ 〜1363, 1959.

32）佐藤武男：喉頭癌一その基礎 と臨床一. 金原出 版, 東京, 1972.

原稿到着：昭和 60 年 1 月 9 日 別刷請求先 : 谷 光毅 T650 神戸市中央区㓓町 7 丁目 神戸大学医学部耳鼻咽喉科学教室 